\title{
FILANTROPI ZAKAT: SOLUSI STABILITAS EKONOMI SYARIAH DI TENGAH PANDEMI COVID 19
}

\author{
Umi Khusnul Khotimah ${ }^{1}$
}

\section{Abstrak}

Tujuan pensyaria'atan zakat dalam Islam adalah kemaslahatan pemilik harta, penerima zakat, dan masyarakat luas. Tujuan tersebut sebagai berikut: pertama, mengurangi kesenjangan sosial di masyarakat. Kedua, membantu orang-orang fakir-miskin yang membutuhkan bantuan secara finansial. Ketiga, pengentasan kemiskinan. Keempat, meningkatkan taraf hidup mustahik. Kelima: membersihkan muzakki dari karakter-karakter negatif yang disematkan Al-Qur'an kepada manusia, seperti kikir dan rakus. Keenam: mengobati hati dari cinta dunia. Ketujuh, melatih diri untuk meneladari satu dari sifat Allah, yaitu pemurah. Kedelapan: menjaga harta agar tidak menjadi incaran orang yang hatinya berpenyakit, seperti iri dan dengki. Kesembilan, sebagai wujud rasa syukur kepada Allah swt atas anugerah nikmat berupa harta. Syariat zakat mempunyai dua dimensi, yaitu ketaatan dan kepedulian sosial. Di tengah wabah corona yang melanda umat manusia, zakat dapat menjadi solusi sebagai stabilisasi ekonomi. Karena dengan distribusi zakat sesuai sasaran tanpa tebang pilih, maka masyarakat miskin tetap mampu membeli kebutuhan sehari-hari. Sehingga putaran ekonomi tidak akan terhenti. Agar dayaguna zakat meningkat, harus diperhatikan kebutuhan mendasar mustahik zakat. Sebagai solusi zakat bisa diberikan dalam bentuk tunai supaya kesulitan ekonomi mereka dapat teratasi. Implentasinya akan lebih mudah jika pembayaran zakat dilaksanakan dengan harga.

Kata Kunci: Zakat, Stabilitas Ekonomi

\section{Abstract}

The purpose of zakat pensyaria'atan in Islam is the benefit of property owners, zakat recipients, and the wider community. These goals are as follows: first, reduce social inequality in society. Second, helping poor people who need help financially. Third, poverty alleviation. Fourth, increasing the standard of living of mustahik. Fifth: to clean the muzakki from the negative characters that the Qur'an has attached to humans, such as being stingy and greedy. Sixth: heal the heart of the love of the world. Seventh, train oneself to be aware of one of Allah's attributes, namely generosity. Eighth: guarding property so as not to become the target of people whose hearts are diseased, such as jealousy and envy. Ninth, as a form of gratitude to Allah SWT for the gift of blessings in the form of wealth. Sharia zakat has two dimensions, namely obedience and social care. In the midst of the

\footnotetext{
${ }^{1}$ Dosen Institiut Ilmu Al Qur'an Jakarta
} 
corona outbreak that hit mankind, zakat can be a solution as an economic stabilization. Because with the distribution of zakat according to the target without selective logging, the poor are still able to buy their daily needs. So that the economic cycle will not stop. In order for the usability of zakat to increase, the basic needs of mustahik zakat must be considered. As a solution, zakat can be given in cash so that their economic difficulties can be overcome. The implication will be easier if zakat payments are made at a price.

Keywords: Zakah, Economic Stability

\section{A. PENDAHULUAN}

Setiap hukum syariat yang ditetapkan Allah swt adalah rahmat yang bertujuan untuk kemaslahatan manusia di dunia maupun di alam baka (Abu Ishaq asy-Syathiby, Al-Muwafaqat fi Ushul as-Syari'ah Jilid 2:322 dan Yusuf Hamid al-'Alim, Al-Maqashid al-'Ammah li asy-Syari'ah alIslamiyyah: 84). Ada yang berbentuk perintah, larangan, dan pilihan yang semuanya mesti dipertanggungjawabkan. Jika ditaati, maka maslahat dan manfaatnya akan kembali pada diri sendiri. Sebaliknya, apabila diingkari, maka mudarat dan kesengsaraan akan menanti segera di dunia atau di akhirat nanti. Diantara hukum syariat yang berupa perintah adalah zakat.

Berbeda dengan empat rukun Islam yang lainya, zakat mempunyai dua dimensi, yaitu ketaatan dan kepedulian. Ketika orang menunaikan zakat berarti sudah taat kepada perintah Allah swt yang Maha Kaya dan sekaligus peduli nasib sesama yang perlu perhatian nyata. Sejarah panjang zakat, sejak awal disyariatkan sampai dengan sekarang selalu mengalami fluktuasi surut atau pasang. Pada masa Rasulullah saw managemen zakat berjalan nyaris tanpa kendala. Begitu Rasulullah saw wafat, sahabat Abu Bakar ash-Shiddiq sudah dihadapkan pada kelompok pembangkang membayar zakat. Jika pada waktu yang sangat dekat dengan Rasulullah saw saja sudah muncul masalah, apalagi 14 abad sesudahnya.

Pada kenyataanya sampai saat ini realisasi zakat masih belum sepenuhnya memberikan jawaban terhadap tujuan pensyariatan. Pemerataan kesejahteraan, turunnya angka kemiskinan, dan berkurangnya ketimpangan sosial dalam kehidupan bermasyarakat merupakan capaian yang diharapkan terwujud melalui zakat. Ibarat jauh panggang dari api, karena harapan tersebut masih sebatas idealisme kalau tidak disebut baru sebatas mimpi. Walau demikian 
segalanya menjadi mungkin dapat tercapai jika terjadi sinergi berbagai pihak yang terkait dengan zakat.

Sesungguhnya, Indonesia merupakan negara yang mempunyai potensi zakat sangat besar. Namun sayangnya realisasi zakat yang masuk ke Baznas masih jauh dari harapan. Walau terus mengalami peningkatan, tetapi realisasi zakat di 3 tahun terakhir masih jauh dari potensi yang ada. Tahun 2018 tercatat hanya Rp 8,1 triliun atau sekitar 3,5 persen dari potensi yang mencapai Rp 252 triliun. Angka tersebut meningkat sebesar 31,8 persen dari pencapaian penghimpunan zakat tahun 2017 (Wartaekonomi, 2018). Di tahun 2019 mencapai Rp 10 triliun dan BAZNAS menargetkan penerimaan zakat di 2020 mencapai Rp 12 triliun (Republika, 2020). Direktur Pendistribusian dan Pemberdayaan BAZNAS Irfan Syauqi Beik pada seminar nasional ekonomi dan keuangan syariah, Festival Ekonomi Syariah (Fesyar) di Surabaya, Jawa Timur, Kamis (7/11/2019) menyebutkan "Potensi zakat luar biasa besar, (mencapai) Rp 233,8 triliun. Terutama potensi zakat profesi." Meskipun demikian, potensi pengusaaan zakat perusahaan masih rendah. Padahal, potensi zakat sebenarnya dapat dioptimalkan dan pada akhirnya menjadi solusi pengembangan perekonomian nasional. Sedangkan ketua BAZNAS Bambang Sudibyo menyebutkan potensi zakat di Indonesia pada tahun 2020 mencapai kisaran angka $340 \mathrm{~T}$. Secara lebih rinci Direktur Baznas M Arifin Purwakananta saat dihubungi Republika, Ahad (8/3/2020) menyebutkan bahwa awal tahun ini, penerimaan zakat rerata naik sekitar 20 persen. Kalau perorangan dan digital malah naik sekitar 35 persen. (Republika, 2020)" Meski capaian masih jauh dari potensi, namun kenaikan pada setiap tahun pantas mendapatkan apresiasi. Potensi yang sangat dasyat tersebut jika dikelola dengan baik, maka aka dapat menyelesaikan berbagai permasalahan ekonomi umat.

Sampai dengan awal Maret 2020, semua rencana dapat berjalan sesuai harapan. Namun, pada kenyataanya Allah swt berkehendak beda. Bulan Maret 2020 menjadi tonggak sejarah perubahan perjalanan bangsa Indonesia bahkan dunia. Musibah yang melanda sebagian negara pada akhir tahun 2019, pada bulan Maret sudah sampai di Indonesia, yaitu virus corona. Bencana yang ditetapkan WHO sebagai pendemi pada tanggal 11 Maret 2020 ini jumlah kasusnya ketika makalah ini ditulis, 25 Juli 2020 sebanyak 15.919 .531 (15,9 juta) kasus. 
Dari angka tersebut, telah terjadi 641.636 kasus kematian dan 9.696.544 (9,7 juta) pasien telah dinyatakan sembuh (Kompas, 2020). Untuk Indonesia pada Jumat (24/7/2020) sebanyak 95.418 kasus, sembuh 53.945 kasus, meninggal 4.665 kasus (detik, 2020).

Selain konban terpapar virus, pandemi juga berakibat pada tingginya angka pemutusan hubungan kerja (PHK). Kemenaker melaporkan tenaga kerja terdampak Covid-19 sekitar 3,05 juta orang (per 2 Juni 2020) dan memperkirakan tambahan pengangguran bisa mencapai 5,23 juta, (Tempo, 2020)" Sebagai negara kepulauan dengan jumlah penduduk 267 juta jiwa pada tahun 2019 penyelesaian persoalan di Indonesia memang menjadi tantangan besar bagi siapapun pemimpinya (Tempo, 2020).

Besarnya angka korban PHK pasti akan berimbas kepada menurunya ekonomi keluarga. Jika hal tersebut tidak terselesaikan dengan baik, pasti akan berakibat pada tingginya kriminal yang akan mengusik keamanan dan ketenangan masyarakat. Dalam kondisi seperti inilah peran zakat menjadi sangat menarik untuk digali. Sebagai satu perangkat dalam ekonomi syariah, zakat telah teruji dalam berbagai situasi mampu untuk memberikan solusi permasalahan ekonomi umat.

\section{B. PENGERTIAN DAN TUJUAN ZAKAT}

Zakat merupakan masdar dari kata zaka yang mempunyai arti berkah, tumbuh, berkembang, bertambah, bersih, baik, suci, dan terpuji (Ibrahim Anis, Mu'jam Wasith, Juz 1: 398). Menurut istilah, zakat adalah sejumlah harta tertentu yang diwajibkan Allah diserahkan kepada orang-orang yang berhak (Qardhawi, 1999:34). Zakat juga bisa berati mengeluarkan jumlah tertentu itu sendiri (Qardhawi, 1999:34). Senada dengan itu Wahbah az-Zuhaili mengatakan zakat adalah memberikan hak yang wajib pada harta. Sedangkan secara urf zakat adalah bagian tertentu dari harta yang telah ditetapkan oleh Allah sebagai hak orang fakir. Lebih jauh Wahbah menjelaskan bahwa zakat disamakan dengan sedekah karena menunjukkan kejujuran hamba dalam beribadah dan taat kepada Allah SWT (Wahbah az-Zuhaili, Jilid 2:730).

Lebih spesifik Malikiyah mendefinisikan zakat adalah mengeluarkan sebagian tertentu dari harta tertentu yang telah sampai nisab kepada orang yang berhak menerima jika kepemilikan genap satu 
tahun sempurna, selain barang tambang, tanaman dan harta temuan. Di sisi lain Hanafiyah lebih menekankan pada kepemilikan, yaitu pemberian hak kepemilikan atas sebagian harta tertentu dari harta tertentu kepada orang lain yang telah ditetapkan oleh syariat sematamata karena Allah SWT (Wahbah az-Zuhaili, Jilid 2: 730-731). Jadi yang dikeluarkan harus esensi barang, tidak boleh hanya manfaatnya saja.

Sementara menurut Syafi'iyah, zakat adalah nama untuk barang yang dikeluarkan dari harta atau badan manusia (zakat fitrah) kepada pihak tertentu. Secara lebih umum Hanabilah mengartikan zakat adalah hak yang wajib pada harta tertentu kepada kelompok tertentu dan di waktu tertentu. Jika diperhatikan, sepertinya Syafiiyah lebih menekankan pada nama yang digunakan untuk sebagian harta yang dikeluarkan sedangkan Hanabilah lebih menekankan pada hak yang harus dikeluarkan.

Dalam Undang-undang zakat No 23 tahun 2011 Bab 1 pasal 1 ayat 2 disebutkan zakat adalah harta yang wajib dikeluarkan oleh seorang muslim atau badan usaha untuk diberikan kepada yang berhak menerimanya sesuai dengan syariat Islam. Definisi ini cakupanya lebih luas, karena memasukkan badan usaha sebagai pihak yang wajib zakat. Berbeda dengan Hanabilah yang menyamakan zakat dengan sedekah, UU No. 23 tahun 2011 memberikan pengertian sedekah adalah harta atau nonharta yang dikeluarkan oleh seseorang atau badan usaha di luar zakat untuk kemaslahatan umum. Adapun infak adalah harta yang dikeluarkan oleh seseorang atau badan usaha di luar zakat untuk kemaslahatan umum.

Jika merujuk pada tujuan pensyaria'atan dalam Islam adalah kemaslahatan, maka wajibnya zakat juga mempunyai tujuan maslahah untuk muzakki, mustahik zakat, dan masyarakat luas. Tujuan tersebut sebagai berikut (Ali Ahmad al-Jurjawi, Hikmah al-Tasyri' wa Falsafatuhu, Jilid 1: 167-177) : pertama, mengurangi kesenjangan sosial di masyarakat. Kedua, membantu orang-orang fakir-miskin yang membutuhkan bantuan secara finansial. Ketiga, pengentasan kemiskinan. Keempat, meningkatkan taraf hidup mustahik. Kelima: membersihkan muzakki dari karakter-karakter negatif yang 
disematkan Al-Qur'an kepada manusia, seperti kikir dan rakus. ${ }^{2}$ Keenam: mengobati hati dari cinta dunia. Ketujuh, melatih diri untuk meneladari satu dari sifat Allah, yaitu pemurah. Kedelapan: menjaga harta agar tidak menjadi incaran orang yang hatinya berpenyakit, seperti iri dan dengki. Kesembilan, sebagai wujud rasa syukur kepada Allah swt atas anugerah nikmat berupa harta.

\section{REGULASI ZAKAT DI INDONESIA}

Sejarah pengelolaan zakat di Indonesia mengalami peningkatan dari masa ke masa meskipun belum mencapai tataran ideal yang diharapkan. Pada zaman kolonial pengumpulan zakat dilakukan secara sukarela individual atas kesadaran pemeluk Islam dalam melaksanakan ajaran agama. Muslim yang membayar zakat sematamata karena menjalankan perintah Allah untuk memperoleh ridhaNya.

Di wilayah tertentu, antara lain Aceh, pada masa pemerintahan Nuruddin Al-Raniri (w. 1658) telah menegakkan ajaran-ajaran Islam dalam pemerintahannya. Negara saat itu telah memiliki institusi dan sistem keuangan yang permanen. Bahkan di masa keemasan Aceh dalam kepemimpinan Sultan Iskandar Muda (1607-1636) negara telah memiliki baitul mal dan sistem 'usyr serta perpajakan. Dengan karakteristik religius dari kekuasaan dapat diperkirakan bahwa negara telah mengumpulkan zakat secara wajib di Aceh, setidaknya walaupun kewajiban zakat tersebut bersifat kewajiban religius individual, akan tetapi negara telah memfasilitasinya (Luknaul Hakim, 2016).

${ }^{2}$ QS. al-Isra'/17: 100; Lihat juga: QS. al-Ma'arij/70: 19-21. Teks lengkapnya Sebagai berikut:

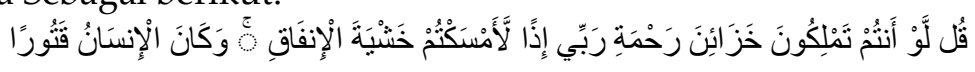

Katakanlah: "Kalau seandainya kamu menguasai perbendaharaanperbendaharaan rahmat Tuhanku, niscaya perbendaharaan itu kamu tahan, karena takut membelanjakannya". Dan adalah manusia itu sangat kikir.

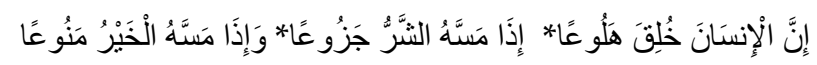

Sesungguhnya manusia diciptakan bersifat keluh kesah lagi kikir. Apabila ia ditimpa kesusahan ia berkeluh kesah, dan apabila ia mendapat kebaikan ia amat kikir. 
Pada tahun 1858 pemerintah Belanda membuat kebijakan bahwa praktik zakat secara umum bersifat netral dan berusaha tidak campur tangan. Bahkan di tahun 1866 pemerintah Belanda membuat regulasi yang melarang seluruh pejabat untuk ikut campur dalam pengumpulan dan pendistribusian dana zakat. Sehingga dana zakat dapat dimanfaatkan untuk kepentingan pendidikan dan kegiatan sosial lainnya. Kebijakan tersebut mengantarkan pada pengumpulan zakat di Jawa terbagi dua; pertama, pengumpulan aktif yang dilakukan oleh penghulu (hakim agama) yang mendapatkan dukungan penuh dari pemerintah setempat, pengumpulan zakat oleh pihak ini bersifat wajib. Kedua, pengumpulan pasif oleh pemuka agama dan bersifat sukarela. Rintisan pengelolaan zakat secara modern dilakukan oleh ormas Muhammadiyah, dengan tiga landasan utama, yaitu teologi al-Mâ'ûn, modernisme dan etos puritan (Lukmanul Hakim, 2016).

Setelah Indonesia merdeka dan terbentuknya Departemen Agama (1946) ada Surat Edaran No. A/VVII/17367 tertanggal 8 Desember 1951 yang menyatakan bahwa Departemen Agama tidak akan ikut campur dalam pengelolaan zakat yang ada, pemerintah hanya memfasilitasi kehidupan beragama. Dalam perkembanganya, tahun 1968, terbit Peraturan Menteri Agama (PMA) No. 4/Juli/1968 tentang pendirian Badan Amin Zakat (BAZ) dan PMA No. 5/Oktober/1968 tentang pendirian Baitul Mal di seluruh daerah yang bertanggung jawab terhadap pengelolaan zakat. Lalu, pada Oktober 1968, Presiden Soeharto mendeklarasikan dirinya sebagai amil zakat nasional personal dan mengundurkan diri dari jabatan tersebut pada November 1970.

Harapan pengelolaan zakat secara profesional tidak pernah pudar. Sejumlah lembaga terus bermunculan dengan nama Badan Amil Zakat, Infak dan Sedekah (BAZIS), Yayasan Amal Bakti Muslim Pancasila (1982) yang menarik dana sedekah dari PNS muslim dengan cara memotong langsung sebagian kecil dari gaji bulanan mereka, dan Yayasan Dharma Bhakti Sosial (Dharmais) yang mengelola pemotongan dana PNS yang non Muslim. Dana tersebut bukan zakat, tetapi sedekah wajib.

Pembentukan BAZIS terus menyebar setelah terbitnya Surat Keputusan Bersama (SKB) Menteri Dalam Negeri dan Menteri Agama No. 29/1991 dan No. 47/1991 tentang Pembinaan BAZIS, yang menjadi dasar legalitas bagi kehadiran BAZ. Lahirnya Organisasi Pengelola 
Zakat (OPZ) nasional yang diawali oleh BAZ Provinsi di era 1970-an, diikuti dengan LAZ berbasis BUMN pada 1980-an, dan diikuti LAZ murni masyarakat sipil di 1990-an, terlihat berjalan beriringan dengan peningkatan pendapatan nasional.

Di era reformasi, lembaga zakat terus menggeliat. Pada tahun 1997 berdirilah Forum Zakat (FOZ) yang kemudian pada 1999 menjadi asosiasi BAZ dan LAZ seluruh Indonesia. Sebagai asosiasi lembaga amil di tingkat nasional, FOZ memegang peran penting dalam membangun jaringan kerja, koordinasi aktivitas anggota, diseminasi informasi hingga advokasi kebijakan pada pemerintah. Akan tetapi dalam praktiknya FOZ dianggap lebih merepresentasikan LAZ yang merupakan bentukan masyarakat sipil, sedangkan BAZ yang merupakan bentukan pemerintah kemudian berhimpun di bawah koordinasi BAZNAS yang beridiri pada 2001.

Berawal pada pada tahun 1985, Departemen Agama dan Departemen Kehakiman telah membuat draf UU Zakat. Usai penandatanganan RUU Haji oleh Presiden Habibie, Departemen Agama segera menyelesaikan draf UU Zakat dan mengirimkannya ke Sekretariat Negara pada April 1999 atas izin prakarsa dari Sekretariat Negara pada Mei 1999. Draf disampaikan ke parlemen pada Juni 1999 dan pembahasan UU dilakukan satu bulan setelahnya. Tepat pada 23 September 1999, UU Zakat disahkan dan zakat secara resmi masuk ke dalam ranah hukum positif di Indonesia. Bulan Desember 1999 UU No, 38/1999 tentang Pengelolaan Zakat ditandatangani oleh Presiden Habibie.

Karena tidak puas dengan UU Zakat yang sudah disahkan, di pertengahan tahun 2000 draf undang-undang pengganti zakat telah disiapkan. Pada Munas FOZ yang ke-3 di tahun 2003 diajukan permintaan secara formal oleh LAZ untuk mengamendemen UU No, 38/1999 tentang Pengelolaan Zakat. Upaya amendemen baru dilakukan di parlemen tahun 2005 di mana RUU Pengelolaan Zakat yang merupakan perubahan atas UU No, 38/1999 masuk dalam program legislasi nasional (Proglegnas) 2005-2009 dan bahkan menjadi RUU prioritas tahun 2009. Namun proses amendemen tersebut tersendat karena tahun 2009 merupakan tahun politik, sehingga anggota parlemen sibuk mempersiapkan proses pesta rakyat, pemilu.

Pembahasan amendemen UU Zakat kembali dilanjutkan oleh DPR periode 2009-2014 melalui RUU inisiatif DPR. Draf undang-undang 
inisiatif DPR keluar pada awal 2010 dan DIM (daftar isian masalah) dari pemerintah keluar pada awal 2011. Setelah dibahas selama dua masa sidang, UU baru Zakat disahkan DPR pada 27 Oktober 2011. Dengan disahkannya UU No. 23 Tahun 2011 menjadi era baru pengelolaan zakat nasional menjadi disentralisasi di tangan pemerintah melalui BAZNAS. Sedangkan nasib LAZ kedudukannya hanya sebagai pembantu BAZNAS dengan salah satu tugasnya untuk memberikan pelaporan ke BAZNAS. Selain sebagai operator, BAZNAS juga memegang fungsi regulator seperti perencanaan, pengendalian, menerima pelaporan dari BAZNAS provinsi, kabupaten/kota dan LAZ, serta berhak mendapat anggaran APBN dan APBD.

Saat ini ada 8 regulasi yang menaungi pengelolaan zakat di Indonesia, sebagai berikut (Baznas, 2020):

1. UU Nomor 23 Tahun 2011 tentang Pengelolaan Zakat;

2. PP 14 Tahun 2014 tentang Pelaksanaan UU Nomor 23 Tahun 2011;

3. PMA Nomor 52 Tahun 2014 tentang Syarat dan Tata Cara Penghitungan Zakat Mal Dan Zakat Fitrah serta Pendauagunaannya untuk Usaha Produktif;

4. PMA Nomor 69 tentang Perubahan atas PMA 52 Tahun 2014;

5. PMA Nomor 5 Tahun 2016 tentang Tata Cara Pengenaan Sanksi Administrasi dalam pengelolaan Zakat.

6. SK Dewan Pertimbangan BAZNAS Nomor 001/DPBAZNAS/XII/2010 tentang Pedoman Pengumpulan dan Pentasharrufan ZIS pada Badan Amil Zakat Nasional;

7. Keputusan Ketua BAZNAS Nomor Kep.016/BP/BAZNAS/XII, tentang Nilai Nishab Zakat Pendapatan atau Profesi tahun 2016;

8. Keputusan Ketua BAZNAS Nomor 142 Tahun 2017 tentang Nilai Nishab Zakat Pendapatan Tahun 2017.

Dari sekian banyak regulasi tentang zakat, belum ada satupun klausul yang mengatur tentang sanksi bagi muzakki yang tidak membayar zakat. Sanksi hanya diberikan kepada pengelolah zakat atau lembaga zakat yang tidak memuhi kewajibanya sesuai undangundang. Disebutkan pada BAB VII pasal 36 bahwa sanksi administratif diberikan berupa peringatan tertulis, penghentian sementara dari 
kegiatan; dan/atau pencabutan izin. Realita rendahnya akumulasi dana zakat yang terkumpul dibandingkan potensi yang ada, mungkin sudah saatnya diwacanakan adanya sanksi bagi muzakki yang enggan membayar zakat. Jika pada masa Kholifah Abu Bakar pembangkang zakat dikategorikan murtad, maka bisa dimusyawarhkan bentuk sanksi yang sesuai untuk pembangkang saat ini.

\section{ZAKAT SEBAGAI SOLUSI STABILITAS EKONOMI}

Dapat dikatakan bahwa penetapan syari'at Islam adalah bersifat prefentif untuk menghindari akibat-akibat negatif. Lima hal mendasar yang dilindungi dalam Islam tiada lain agar manusia tidak semenamena dalam mendayagunakan anugerah Allah Yang Maha Pemurah. Zakat merupakan kewajiban umat Islam yang berkaitan dengan satu dari lima hal mendasar tersebut, yaitu harta.

Pengertian harta adalah setiap yang dimiliki dan digenggam atau dikuasai manusia secara nyata, baik berupa benda maupun manfaat, seperti emas, perak, hewa, tumbuh-tumbuhan atau manfaat barang seperti mengendarai dan menempati (Wahbah Az-Zuhaili, Fighul Islami wa Adillatuhu: Jilid 4: 40). Tim Ensiklopedi Hukum Islam mendefinisikan harta adalah segala sesuatu yang menyenangkan manusia dan mereka pelihara, baik dalam bentuk materi maupun manfaat (Ensiklopedi Hukum Islam Jilid 2, 1996: 525).

Berbeda dengan definisi di atas ulama Hanafiyah mengatakan bahwa harta adalah segala sesuatu yang mungkin digenggam serta biasa dimanfaatkan baik oleh seluruh maupun sebagian manusia (Ibnu Abidin, 1996:3), atau segala sesuatu yang dapat dimiliki, disimpan dan dimanfaatkan ((Ensiklopedi Hukum Islam Jilid 2, 1996: 525). Mereka membatasi harta hanya pada barang-barang yang bersifat materi. Sedangkan hak dan manfaat (kegunaan yang dihasilnya oleh barang/materi seperti mengendarai kendaraan, menggunakan pakaian, mendiami rumah dan sebagainya) tidak termasuk di dalamnya. Maka tidaklah termasuk harta sesuatu yang abstrak, seperti ilmu dan kecerdasan, dan tidak termasuk harta sesuatu yang tidak biasa dimanfaatkan seperti makanan basi, sebiji beras atau setetes air. Juga tidak termasuk harta sesuatu yang dimanfaatkan dalam keadaan darurat. Sedangkan menurut Jumhur Ulama, harta adalah setiap yang mempunyai nilai dan jika rusak maka orang yang merusaknya harus mengganti (As-Suyuthi, Asybah wan-Nazhair: 258). Mereka mengatakan 
bahwa manfaat suatu benda/materi termasuk kategori harta. Justru manfaat suatu benda merupakan unsur terpenting dalam harta. Oleh karena itu tidak boleh menggunakan/memanfaatkan barang orang lain walaupun tidak mengambil barangnya.

Dari beberapa definisi di atas dapat disimpulkan bahwa harta adalah benda yang dapat dikuasai dan menyenangkan manusia, baik materi maupun manfaatnya. Karena nilai suatu benda sebagai harta diukur dari manfaat benda tersebut. Apalah artinya suatu benda jika tidak ada manfaatnya. Oleh karena itu pemilik harta menguasai materi dan manfaatnya serta berhak menuntut ganti rugi jika ada pihak yang menyalahgunakan.

Walau ada berbagai jenis harta yang dimiliki manusia, hanya tertentu saja yang diwajibkan zakat, yaitu: emas, perak, logam mulia, uang, surat berharga, perniagaan, pertanian, perkebunan, kehutanan, peternakan, perikanan, pertambangan, perindustrian, pendapatan dan jasa, serta rikaz. Itulah yang dimaksud dengan zakat mal dalam UU zakat. Selain itu masih ada satu jenis zakat, yaitu zakat fitrah atau zakat nyawa/jiwa.

Islam sudah menetapkan kepada siapa saja zakat harus didistribusikan. Ada delapan golongan mustahik zakat sebagaimana disebutkan dalam QS. At-Taubah ayat 60:

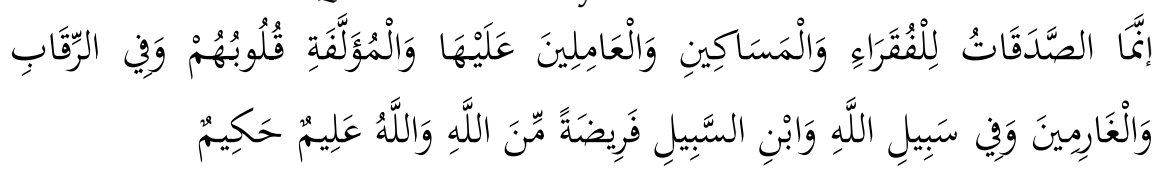

Artinya:

"Sesungguhnya zakat-zakat itu, hanyalah untuk orang-orang fakir, orangorang miskin, pengurus-pengurus zakat, para mu'allaf yang dibujuk hatinya, untuk (memerdekakan) budak, orang-orang yang berhutang, untuk jalan Allah dan untuk mereka yuang sedang dalam perjalanan, sebagai suatu ketetapan yang diwajibkan Allah, dan Allah Maha Mengetahui lagi Maha Bijaksana."

Secara berurutan yang disebut di awal dalam ayat Al-Qur'an adalah fakir lalu miskin. Memang Islam mempunyai perhatian yang sangat besar kepada kelompok ini. Beragam jenis ungkapan Al-Qur'an untuk memperhatikan fakir dan miskin (QS. Muddatstsir/74: 38-44; QS. al-Qalam/68: 19-33; QS. Al-Haqqah/69: 30-34; QS. Al-Fajr/89: 17-18; QS. Adz-Dzariyat/51: 19-20; QS. Al-Isra'/17: 26; QS. Ar-Rum/30: 38; QS. Al- 
Ma'un/107: 1-3.) antara lain, memberi makan, mengeluarkan sebagian rizki, memberikan hak orang yang minta-minta, orang terlantar, bahkan memberi predikat sebagai pendusta agama kepada siapapun yang tidak mau menganjurkan memberi makan orang miskin.

Di Idonesia, pandemi cavid-19 berakibat pada meningkatnya jumlah penduduk miskin karena menurunnya pendapatan bahkan banyak yang kehilangan pekerjaan. Menurut Bank Dunia (2020) hanya ada lima kelompok masyarakat Indonesia. Pertama, miskin, yaitu masyarakat yang pengeluaran bulanannya kurang dari Rp 354 ribu per bulan. Kedua, rentan, yaitu masyarakat yang berada di garis kemiskinan tetapi rentan untuk jadi miskin dengan pengeluaran antara Rp 354 ribu hingga Rp 532 ribu. Ketiga, menuju kelas menengah, yaitu masyarakat yang masih belum aman meskipun tidak miskin atau rentan dengan pengeluaran antara Rp532 ribu hingga Rp1,2 juta. Keempat, kelas menengah, yaitu masyarakat yang sudah aman secara ekonomi dan jauh dari miskin atau rentan dengan pengeluaran dari Rp1,2 juta hingga Rp 6 juta. Kelima, kelas atas, yaitu masyarakat yang paling sejahtera dengan pengeluaran lebih dari Rp 6 juta per orang. Dari kelima kelompok masyarakat tersebut, paling banyak adalah kelompok Menuju Kelas Menengah dengan 114,7 juta jiwa atau sekitar 44 persen. Kedua adalah kelompok Rentan dengan 61,6 juta orang atau 23,6 persen. Ketiga adalah kelas Menengah dengan 53,6 juta orang atau 20,5 persen. Selanjutnya ada kelas Miskin, berjumlah 28 juta orang atau 10,7 persen dan kelas Atas, berjumlah 3,1 juta orang atau 1,2 persen. Hasil survei menunjukkan bahwa pendapatan seluruh masyarakat menurun, khususnya masyarakat berpendapatan rendah. Di mana 7 dari 10 masyarakat pendapatan rendah di bawah $\mathrm{Rp} 1,8$ juta terpengaruh. Bahkan masyarakat pendapatan tinggi di atas Rp 2,7 juta juga turun pendapatannya (CNN Indonesia, 2020). Badan Pusat Statistik (BPS) mencatat angka kemiskinan di Indonesia pada September 2019 sebesar 9,22 persen atau setara dengan 24,97 juta orang. Angka tersebut lebih rendah 0,19 persen atau sekitar 358.900 dibandingkan periode Maret 2019 (Kompas, 2020). Kepala BPS Suhariyanto dalam konferensi pers virtual, Rabu (15/7/2020) menjelaskan bahwa Maret 2020 angka kemiskinan mengalami kenaikan menjadi 26,42 juta orang atau 9,78 persen. Jadi mengalami kenaikan 1,63 juta orang atau $0,56 \%$. Perhitungan angka kemiskinan yang digunakan BPS pada Maret 2020 menggunakan garis kemiskinan Rp 452.652 per 
kapita per bulan. Komposisi garis kemiskinan didominasi 73,86 persen dari kelompok makanan seperti beras sampai rokok kretek filter dan sisanya 26,14 persen bukan makanan, seperti biaya perumahan, bensin, listrik sampai pendidikan (Tirto, 2020).

Peningkatan tingkat kemiskinan tidak hanya terjadi di desa, tetapi juga di kota. Bahkan di kota mencapai 1,12 persen poin dari September 2019 yang berkisar 6,56 persen menjadi 7,38 persen. Sementara di desa lebih landai dengan kisaran 0,22 persen dari 12,60 persen menjadi 12,82 persen. Jika dilihat menurut provinsi, dampak COVID-19 yang baru terekam beberapa minggu dalam survei BPS Maret 2020 menunjukan hampir seluruh daerah mengalami kenaikan. Dari 34 provinsi, 22 diantaranya mengalami kenaikan tingkat kemiskinan. "Seluruh provinsi di Jawa mengalami kenaikan kemiskinan dan tertinggi di DKI Jakarta yaitu 1,11 persen poin (3,42 persen menjadi 4,53 persen). Sementara penurunan tertinggi di Sulawesi Tengah 0,26 persen poin (Tirto, 2020).

Melalui teleconference, Rabu (6/5/2020), Menteri Keuangan Sri Mulyani Indrawati mengatakan, pandemi Covid-19 akan berdampak pada jumlah kemiskinan di RI. Bahkan persentase kemiskinan pada Maret tahun ini bisa kembali ke double digit seperti tahun 2011 yang mencapai 30,02 juta orang atau berada di level 12,49\%. Kondisi tersebut menjadi semakin parah dengan data dari Kementerian Ketenagakerjaan yang mencatat angka pengangguran selama masa Covid ini bertambah sekitar 2 juta orang (CNBC Indonesia, 2020).

Langkah yang sudah dilakukan pemerintah agar kemiskinan tidak terlalu melonjak tinggi selama masa pandemi ini adalah melalui bantuan sosial dengan mengeluarkan anggaran tidak sedikit, terutama kepada masyarakat miskin dan terkena PHK. Pemerintah perlu melakukan langkah-langah agar badai PHK oleh perusahaan bisa diminimalisir. Diantaranya adalah memberikan insentif bagi perusahaan yang paling terdampak melalui perpajakan. Selain itu ada juga kartu prakerja untuk membantu masyarakat yang sudah ter-PHK agar mendapatkan bantuan. Juga fokus ke Prakerja yang bisa cover 5,6 juta orang yang bentuknya setengah bantuan sosial. Itulah langkahlangkah yang sudah dilakukan untuk menangani PHK (CNBC Indonesia, 2020). 
Terkait Zakat, Ditengah wabah Covid-19, BAZNAS dan LAZ telah memberikan bantuan, antara lain berupa pengadaan Alat Pelindung Diri (APD) untuk tenaga medis, pembagian masker, handsinitizer, penyemprotan disinfektan di area publik, pembagian paket sembako dan makanan siap saji, dan edukasi kepada masyarakat (Baznas, 2020). Bekerja sama dengan Badan Nasional Penanggulangan Bencana (BNPB) serta Forum Relawan Divabel (Fordiva) menggelar kegiatan pelayanan cek rapid test Covid-19 masal untuk para penyandang disabilitas serentak di tiga kota yaitu, Surabaya, Depok, dan Bekasi, pada Sabtu (30/5/2020). Pada kesempatan yang sama BAZNAS juga mendistribusikan makanan sehat sebagai pendukung gizi tambahan, masker dan hand sanitizer untuk para penyandang disabilitas yang menjalani tes. Tak hanya itu, Baznas juga memberikan dukungan ambulans di tiga titik lokasi digelarnya rapid test untuk memudahkan mobilitas para penerima manfaat. Lebih dari itu BAZNAS berkomitmen untuk bisa meningkatkan kualitas hidup para penerima manfaat, dengan memberikan langkah edukasi, atau pencegahan terhadap suatu wabah penyakit (Baznas, 2020)".

Dengan mengusung tema "New Normal New Spirit" di tahun 2020, Sekolah Cendekia BAZNAS adalah salah satu program pendidikan yang dikelola BAZNAS dimana tujuan didirikan adalah untuk mengakomodir anak dhuafa berprestasi dari seluruh pelosok negeri yang mengalami keterbatasan untuk mendapatkan akses pendidikan karena masalah ekonomi. Setiap siswa menempuh pendidikan sesuai kurikulum dinas pendidikan, pembinaan karakter islam, quran-hadist serta pengembangan potensi sesuai minat dan bakat (Baznas, 2020).

Tidak hanya di tingkat pusat, BAZNAS daerah juga melaksanakan distribusi dalam bentuk bantuan langsung tunai, sembako kepada faqir miskin, penyandang disabilitas, pengurus masjid dan madrasah, serta marbot masjid. Juga pemberian kursi roda, pemberian kaki palsu, dan rehabilitasi mushola yang bekerjasama dengan Walicare (Satelitnews, 2020). Bahkan BAZNAS DKI Jakarta sukses membangun 385 rumah dhuafa, WC komunal, listrik, dan sebagainya di tahun 2019. BAZNAS juga tebus Ijazah Tertahan di 79 Sekolah hingga harus bayar Rp 688 Juta (Detik, 2020).

Dari sejumlah distribusi Baznas kepada mustahik menunjukkan bahwa peran zakat sangat besar dalam membantu berbagai macam 
broblem ekonomi masyarakat. Jika saat ini baru 3,5\% dari potensi yang terkumpul, maka PR besarnya adalah mencari strategi meningkatkan supaya lebih besar lagi agar tujuan pensyariatan zakat dapat tercapai.

Syariat zakat mempunyai dua dimensi, yaitu ketaatan dan kepedulian yang bertujuan untuk kemaslahatan. Inilah yang membedakan zakat dengan ibadah lainya. Kewajiban menunaikan zakat bagi muzakki berkaitan dengan hak mustahik. Artinya, jika zakat tidak dilaksanakan, maka ada hak pihak lain yang dilanggar. Oleh karena itu pelaksanaan zakat harus mempertimbangkan kebutuhan utama masyarat di tempat zakat ditunaikan. Merujuk kepada data BPS bahwa 73,86 persen garis kemiskinan adalah makanan dan 26,14 persen selain makanan, biaya rumah, bensin, listrik dan pendidikan. Memperhatikan kondisi tersebut, maka saat pandemi seperti sekarang ini menurut hemat saya prioritas distribusi harusnya berupa bantuan tunai. Sehingga mustahik dapat memenuhi kebutuhan utamanya dan roda perekonomian tetap berjalan, karena daya beli mereka tidak terhenti. Sepertinya di situasi pandemi masyarakat miskin harapanya sebatas bisa bertahan untuk memenuhi kebutuhan mendasar, karena telah kehilangan pekerjaan. Sedangkan setiap orang mempunyai kebutuhan utama yang berbeda antara satu dengan lainya.

Cara lain yang bisa ditempuh adalah mempercepat mengeluarkan zakat. Sebagai satu dari sekian perintah agama, idealnya zakat dilaksanakan dengan segera. Karena penundaan zakat dapat berakibat mudarat bagi mustahiknya. Kecuali jika disegerakan akan membawa mudarat pada harta atau pemiliknya. Rasulullah saw mengajarkan untuk tidak berbuat mudarat kepada siapapun juga, walau kepada orang yang sudah berbuat zalim kepada kita. Di tengah wabah pandemi kebutuhan terhadap harta zakat semakin meningkat seiring naiknya angka kemiskinan. Sehingga mempercepat membayar zakat dapat menjadi wajib, karena mustahik sangat membutuhkan, apabila harta sudah mencapai nisab (Al-Qardhawi, 1999: 813). Sebagian ulama mengatakan tidak wajib tetapi boleh dikeluarkan sebelum haul (Ibnu Rusyd, Bidayah al-Mujtahid, Jilid 1: 266). Majlis Ulama Indonesia melalui Fatwa Nomor 23 Tahun 2020 ttg Pemanfaatan Harta Zakat, Infak dan Shadaqah untuk Penanggulangan Wabah Covid-19 dan Dampaknya, dalam Ketentuan Hukum ayat 2 disebutkan: Zakat mal boleh ditunaikan dan disalurkan lebih cepat (ta'jil al-zakah) tanpa harus 
menunggu satu tahun penuh (hawalan al-haul), apabila telah mencapai nishab (Fatwa Majelis Ulama Indonesia tentangg Pemanfaatan Harta Zakat, Infak dan Shadaqah untuk Penanggulangan Wabah Covid-19 dan Dampaknya). Anjuran percepatan pembayaran dan distribusi zakat disampaikan oleh Wakil Presiden RI, KH. Ma'ruf Amin, Mentri Agama RI, Fachrul Razi, PBNU, dan PP Muhammadiyah (Forum Zakat, 2020). Agar para muzakki tergugah hati untuk melaksanakan anjuran tersebut, maka pihak-pihak terkait harus lebih giat melakukan sosialisasi dan publikasi tanpa benti.

Hal lain yang juga perting diperhatikan dalam pengelolaan zakat adalah distribusi. Berbicara tentang distribusi sangat tergantung kepada pengelola zakat. Harta zakat harus segera didistribusikan kepada mustahik zakat. Terdapat perbedaan ulama fikih tentang kebolehan memindahkan zakat dari tempat penghasil zakat. Apabila wilayah penghasil zakat masih memerlukan, maka lebih baik zakat didistribusikan di daerah tersebut, kecuali dialihkan untuk kerabat. Namun, jika di daerah yang bukan penghasil zakat lebih memerlukan dibandingkan penduduk setempat, maka boleh dialihkan. Begitu juga bila di daerah penghasil zakat tidak ada lagi mustahik, maka hukumnya menjadi wajib dialihkan (Qardhawi, 1999:802). Dibolehkan juga bila ada pertimbangan penguasa kalau dialihkan akan lebih manfaat. Wacana tersebut semakin memperkuat bahwa syariat zakat adalah untuk kemaslahatan. Oleh karena itu distribusi zakat harus memerhatikan mustahik yang lebih membutuhkan dan manfaat atau maslahat yang lebih besar.

Agar harta zakat lebih mudah terdistribusi, maka pengelolah perlu mempertimbangkan pembayaran zakat dengan harga. Pada prinsipnya taklif dalam Islam adalah 'adam al-haraj, tidak menyulitkan atau tidak mempersulit. Oleh karena itu sebagian ulama membolehkan mengeluarkan zakat dengan harga jika itu mempermudah pemilik harta untuk menunaikan. Karena tujuan zakat adalah menutup kebutuhan mustahik dan mewujudkan kemaslahatan umat. Di tengah pandemi cavid-19 orang dilarang berkerumun. Jika terpaksa harus bertemu maka harus menjaga jarak dan tidak dalam waktu lama. Jika demikian situasinya, maka pembayaran zakat dengan harga jelas akan mempermudah pemilik harta, pengelolah dan penerima. Dengan bantuan teknologi yang canggih semuanya bisa dilaksanakan secara on-line. 
Zakat memang perintah agama, sehingga pemberi sanksi bagi yang tidak menunaikan zakat adalah Allah swt. Namun, di sisi lain zakat juga berkaitan dengan manusia yang berhak menerimanya. Ketika hukum zakat sudah masuk dalam hukum negara, maka sudah sepatutnya negara turun tangan ketika ada yang tidak menjalankannya. Jika sanksi belum bisa dilaksanakan secara merata, maka memulai dari yang mudah mungkin bisa dicoba. Direktur Pendistribusian dan Pemberdayaan BAZNAS Irfan Syauqi Beik mengatakan bahwa potensi pengusaaan zakat perusahaan masih rendah, padahal di sanalah potensi zakat yang melimpah. Untuk efektifnya pemberlakuan UU Zakat, maka patut dicoba penerapan sanksi pembangkang zakat secara bertahap.

Untuk pembiasaan taat zakat bisa dimulai dari melaksanakan yang sunat/sunah, yaitu infak dan sedekah. Berlatih menjadi pemurah harus dimulai dari mengeluarkan yang ringan. Infak dan sedekah tidak ada batasan minimalnya, jadi bisa dilaksanakan dengan jumlah berapa saja bahkan dalam bentuk apapun yang ada manfaatnya. Bahkan Rasulullah saw pernah menyebut separuh kurma bisa untuk bersedekah. Sebaiknya sedekah dilaksanakan dengan sukarela dan sukacita, karena akan menggembirakan penerimanya. Di tengah wabah corona, infak dan sedekah akan meringankan beban masyarakat terdampak. Apalagi bila dilaksanakan secara bersama-sama, maka semakin banyak pula masyarakat yang akan mendapatkan manfaatnya.

\section{ZAKAT SEBAGAI SOLUSI STABILITAS EKONOMI}

Zakat adalah sejumlah harta tertentu yang diwajibkan Allah diserahkan kepada orang-orang yang berhak. Zakat juga bisa berati mengeluarkan jumlah tertentu itu sendiri. Secara lebih luas pengertian zakat adalah harta yang wajib dikeluarkan oleh seorang muslim atau badan usaha untuk diberikan kepada yang berhak menerimanya sesuai dengan syariat Islam. Zakat berbeda dengan infak dan sedekah. Infak adalah harta yang dikeluarkan oleh seseorang atau badan usaha di luar zakat untuk kemaslahatan umum. Sedangkan sedekah adalah harta atau nonharta yang dikeluarkan oleh seseorang atau badan usaha di luar zakat untuk kemaslahatan umum. 
Adapun tujuan pensyaria'atan zakat dalam Islam adalah kemaslahatan pemilik harta, penerima zakat, dan masyarakat luas. Tujuan tersebut sebagai berikut: pertama, mengurangi kesenjangan sosial di masyarakat. Kedua, membantu orang-orang fakir-miskin yang membutuhkan bantuan secara finansial. Ketiga, pengentasan kemiskinan. Keempat, meningkatkan taraf hidup mustahik. Kelima: membersihkan muzakki dari karakter-karakter negatif yang disematkan Al-Qur' an kepada manusia, seperti kikir dan rakus (QS. alIsra'/17: 100; Lihat juga: QS. al-Ma'arij/70: 19-21). Keenam: mengobati hati dari cinta dunia. Ketujuh, melatih diri untuk meneladari satu dari sifat Allah, yaitu pemurah. Kedelapan: menjaga harta agar tidak menjadi incaran orang yang hatinya berpenyakit, seperti iri dan dengki. Kesembilan, sebagai wujud rasa syukur kepada Allah swt atas anugerah nikmat berupa harta.

Syariat zakat mempunyai dua dimensi, yaitu ketaatan dan kepedulian sosial. Di tengah wabah corona yang melanda umat manusia, zakat dapat menjadi solusi sebagai stabilisasi ekonomi. Karena dengan distribusi zakat sesuai sasaran tanpa tebang pilih, maka masyarakat miskin tetap mampu membeli kebutuhan sehari-hari. Sehingga putaran ekonomi tidak akan terhenti. Agar dayaguna zakat meningkat, harus diperhatikan kebutuhan mendasar mustahik zakat. Sebagai solusi zakat bisa diberikan dalam bentuk tunai supaya kesulitan ekonomi mereka dapat teratasi. Implentasinya akan lebih mudah jika pembayaran zakat dilaksanakan dengan harga.

Pada situasi pandemi seperti saat ini perlu dilakukan edukasi dan sosialisai percepatan pembayaran zakat. Meningkatnya angka kemiskinan akibat wabah, akan meningkat pula masyarakat yang memerlukan dana zakat. Sehingga akan lebih manfaat jika pembayaran zakat dipercepat. Jika sudah sampai pada saat yang tepat diperlukan inovasi penguatan kuantitas dan kualitas zakat antara lain penerapan sanksi pembangkang zakat secara bertahap.

\section{DAFTAR PUSTAKA}

Abidin, Ibnu. (1966). Hasyiyah Radd Al-Mukhtar Jilid 4. Kairo: Musthafa al-Babi al-Halabi.

Al-Jurjâwîy, Ali Ahmad Hikmat. (1994). Al- Tasyrî́ wa Falsafatuhu. Beirut: Daar al- Fikr. 
Al-Qardhawi, Yusuf. (1999). Hukum Zakat. Bogor: Litera Antar Nusa. Anis, Ibrahim et. al. (1972). Al-Mu'jam Al-Wasit. Kairo: Majma' AlLughah AlArabiyyah.

Arabi, Ibnu (t.t). Ahkam Al-Qur'an.

As-Syatibi , Abu Ishaq. (1997). Al-Muwafaqat fi ushul al-Syari'ah. Beirut: Darul Ma'rifah.

As-Suyuthi, Jalaluddin. (1983). Al-Asybah wan Nadha ir. Beirut: Darul Kutub Alllmiyyah.

Az-Zuhaili, Wahbah. (2011). Fiqih Islam Wa Adillatuhu. Terj. Abdul Hayyie al-Kattani. Jakarta: Gema Insani.

Ensiklopedi Hukum Islam Jilid 2. (Ed. Abdul Aziz Dahlan). Jakarta: Ichtiar Baru Van Hoeve. (1996).

Majelis Ulama Indonesia, Fatwa Nomor 23 Tahun 2020 ttg Pemanfaatan Harta Zakat, Infak dan Shadaqah untuk Penanggulangan Wabah Covid-19 dan Dampaknya, Jakarta 16 April 2020

Rusyd, Ibnu. (1989). Bidayah al-Mujtahid Wa Nihayah Al-Muqtasid, Jlidi 2. Beirut: Dar al-Jiil.

Shihab, Quraish. (2010). Al-Qur'an dan Maknanya. Tangerang: Lentera Hati.

Yusuf Hamid. (t.t). al-'Alim, Al-Maqashid al-'Ammah li asy-Syari' ah alIslamiyyah. Dar al-Hadits.

\section{Website:}

Awal penerimaan Zakat Digital Baznas Naik 35 Persen. (https://republika.co.id/berita/q6vjvh415/awal-2020-penerimaanzakat-digital-baznas-naik-35-persen: 8 Maret 2020; 21.19).

Baznas DKI akan Bedah 600 Rumah Kaum Dhuafa Sepanjang 2020. (https://news.detik.com/berita/d-4907240/baznas-dki-akanbedah-600-rumah-kaum-duafa-sepanjang-2020, 20 Feb 2020)

Baznas Selenggarakan Rapid Test untuk Diasbilitas. (https://baznas.go.id/pendistribusian/baznas/2548-baznasselenggarakan-rapid-test-untuk-disabilitas, 4 Juni 2020) 
BPS Proyeksi Jumlah Pendudukan Indoensia 319 Juta Jiwa pada 2045. (https://bisnis.tempo.co/read/1307583/bps-proyeksi-jumlahpenduduk-indonesia-319-juta-jiwa-pada-2045/full\&view=ok: Jum;at 14 Februari 2020; 14.42)

Dampak Covid-19 Angka Kemiskinan Indonesia Melonjak 264 Juta. (https://tirto.id/dampak-covid-19-angka-kemiskinan-indonesiamelonjak-264-juta-

fQ9M\#: :text=tirto.id\%20\%2D\%20Badan\%20Pusat\%20Statistik,s ebelumnya\%2025\%2C14\%20juta\%20orang.)(15 Juli 2020)

Dampak Corona 305 Juta Orang Terkena PHK hingga Juni. (https://bisnis.tempo.co/read/1350955/dampak-corona-305-jutaorang-terkena-phk-hingga-juni/full\&view=ok:) 8 Juni 2020.

Lukmanul Hakim, Regulasi Zakat di Indonesia, Kebijakan Setengah Hati. Regulasi Zakat di Indonesia, Kebijakan Setengah Hati. (https://www.kompasiana.com/lukman45/569e66af177b61fc0c4e 5c59/regulasi-zakat-di-indonesia-kebijakan-setengahhati?page=all: 19 Januari 2016)

Pendayagunaan Zakat di Era pandemi Covid-19. (https://forumzakat.org/pendayagunaan-zakat-di-era-pandemicovid-19-vol-1/, 21 April 2020)

Penduduk Miskin RI Membengkak Jadi 26,42 Juta karena Corona. (https://www.cnnindonesia.com/ekonomi/20200715121015-532524894/penduduk-miskin-ri-membengkak-jadi-2642-jutakarena-corona). Rabu, 15/07/2020

Pengelolaan Zakat. https://pid.baznas.go.id/pengelolaan-zakat/ Penghimpunan Zakat baznas Naik 318 Persen. (https://www.wartaekonomi.co.id/read209482/2018penghimpunan-zakat-baznas-naik-318-persen: Jumat 28/12/2018).

Potensi Zakat di Indoensia Besar. (https://money.kompas.com/read/2019/11/07/153000126/potensizakat-di-indonesia-sangat-besar-tetapi-?page=all)

Sekolah Baznas usung Tema New Normal Spirit. (https://baznas.go.id/pendistribusian/baznas/2970-sekolahcendekia-baznas-usung-tema-new-normal-new-spirit, 16 Juli 2020) 
Sri Mulyani: Jumlah Penduduk Miskon di 2020 Bakal Bertambah. (https://www.cnbcindonesia.com/news/20200506145255-4156728/sri-mulyani-jumlah-penduduk-miskin-di-2020-bakalbertambah. 6 Mei 2020)

NU dan Muhammadiyah Upayakan Percepatan pembayaran Zakat. https://republika.co.id/berita/q9e96w327/nu-danmuhamamdiyah-upayakan-percepatan-pembayaran-zakat (26 April 2020)

Turun Tipis Jumlah Orang Miskin di Indonesia Capai 24,79 Juta. (https://money.kompas.com/read/2020/01/15/173644026/turuntipis-jumlah-orang-miskin-di-indonesia-capai-2479juta\#: :text=JAKARTA\%2C\%20KOMPAS.com\%20\%2D\%20Bada n,setara\%20dengan\%2024\%2C97\%20orang.(15/01/2020)

Update Corona di Dunia 25 Juli 15,9 Juta Terinfeksi. (https://www.kompas.com/tren/read/2020/07/25/072500965/upd ate-corona-di-dunia-25-juli--15-9-juta-terinfeksi-kasus-kematianpertama? Dilansir dari laman Worldometers, Sabtu (25/7/2020) pagi.

Update Corona Indoensia 24 Juli, 95.418 Positif dan 53.945 Sembuh. (https://health.detik.com/berita-detikhealth/d-5106499/updatecorona-indonesia-24-juli-95418-positif-53945-sembuh). 